\section{Lipoleiomyoma associated to uterine prolapse: a case report}

\section{Lipoleiomioma associado à prolapso uterino: relato de caso}

Dino Roberto Soares De Lorenzi 1

Luzia Fernanda Lucena 2
1 Unidade de Ensino em Tocoginecologia. Universidade de Caxias do Sul. Rua Francisco Getúlio Vargas, 1130. Petrópolis. Caxias do Sul, RS, Brasil. CEP: 95.070-560. E-mail: dlorenzi@terra.com.br

2 Serviço de Ginecologia. Irmandade da Santa Casa de Misericórdia de Porto Alegre. Universidade Federal de Ciências da Saúde de Porto Alegre. Porto alegre, RS, Brasil.

\begin{abstract}
Introduction: lipoleiomyoma is a rare benign tumor of the uterus, with an incidence ranging between $0.03 \%$ and $0.2 \%$.

Description: the authors report a case of lipoleiomyoma diagnosis in an 82-year-old woman with a totally prolapsed uterus.

Discussion: lipoleiomyoma is most common among postmenopausal women and is associated with ordinary leiomyomas. Histologically it is composed of smooth muscle, adipocytes and fibrous tissue. In general asymptomatic, the diagnosis usually involves imaging studies such as ultrasound and computed tomography of the pelvis.
\end{abstract}

Key words Lipoleiomyoma, Lipomatous uterine tumor Uterine lipoma, Uterine fibromyolipoma

\section{Resumen}

Introdução: lipoleiomioma é um raro tumor benigno do útero, com uma incidência variando entre $0,03 \%$ e $0,2 \%$.

Descrição: os autores relatam um caso de diagnóstico ocasional de lipoleiomioma ocorrido em uma mulher de 82 anos e com prolapso uterino total.

Discussão: o lipoleiomioma é mais frequente entre mulheres pós-menopáusicas associado a leiomiomas comuns. Histologicamente é composto por músculo liso, adipócitos e tecido fibroso. Em geral assintomático, o diagnóstico envolve normalmente estudos de imagem como ultrassom e tomografia computadorizada da pelve.

Palavras-chave Lipoleiomioma, Tumor lipomatoso do útero, Lipoma uterino, Fibromiolipoma uterino 


\section{Introduction}

Lipoleiomyoma is rare kind of mesenchymal neoplasm of uterus, considered a possible variation of ordinary leiomyoma, whose incidence is less than $0.2 \%$ of all benign uterine tumors. It is also called fibrolipoleiomyoma, benign mixed mesodermal tumor or uterine lipomatous tumor. 1-3

Such tumors are usually found in postmenopausal women aged between 50 and 75 years and are predominantly intramural. Histologically, lipoleiomyomas are composed of variable amounts of smooth muscle, adipocytes and fibrous tissue. Fatty metamorphosis of smooth muscle cells of ordinary leiomyomas is the most likely factor involved in the development of lipoleiomyomas. $1,2,4$

Most cases of lipoleiomyoma are asymptomatic, although palpable mass, hypermenorrhea and pelvic discomfort or even pain may occur.4,5 Pre-operatory diagnosis is possible using radiological imaging studies, such as ultrasound or computed tomography scanning of pelvis, but the condition may be misdiagnosed as an ovarian teratoma or even another uterine neoplasm.2,6,7
Given its low incidence, we report a case of an 82-year-old woman with lipoleiomyoma in a totally prolapsed uterus. The diagnosis was incidental following a vaginal hysterectomy. Its publication was previously authorized in writing by the patient, whose identity will be kept confidential.

\section{Description}

In April, 2008, an 82-year-old woman attended the Gynecological Surgery Service of the Caxias do Sul Medical School to be evaluated for a total uterine prolapse. Transvaginal ultrasound scanning showed a small uterus with a volume of $23-\mathrm{cm} 3$, without anexial tumors. The miometrium was ultrasonographically heterogeneous and the endometrium showed a thickness of 3.4-mm.

The patient underwent a vaginal hysterectomy. The pathologic cross section of the uterus revealed a 2.7$\mathrm{cm}$ well-circumscribed subserosous tumor with yellowish and gray areas. Histopathologically, the tumor was shown to be a lipoleiomyoma, consisting of smooth muscle cells and mature adipose tissue (Figure 1).

\section{Figure 1}

Pathological anatomy-Hematoxylin-Eosin colouring showing the histological mixture of adipose tissue and smooth muscle.

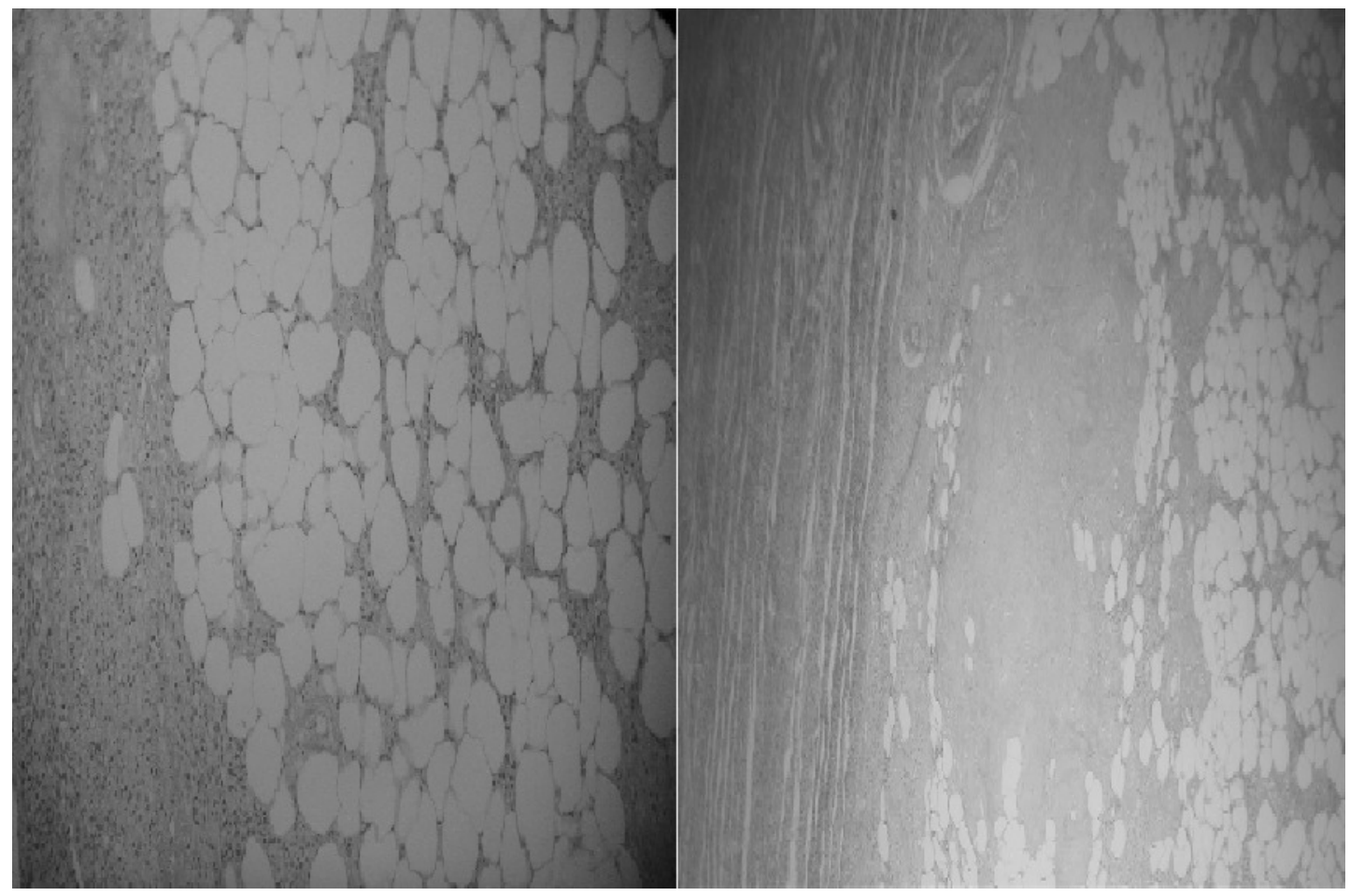




\section{Discussion}

Uterine lipoleiomyomas occurs predominantly among postmenopausal women aged between 50 and 80 years, with an incidence that ranges from $0.03 \%$ to $0.20 \%$ of all leiomyomas. ${ }^{2,5,6}$ Malignant degeneration is extremely rare, according to the literature and only one case of leiomyolipoarcoma has been reported. 8

This lipomatous tumor is a variation of leiomyoma and consists of smooth muscle cells, mature adipose tissue and fibrous tissue with a wellencapsulated benign growth.4,8,9 The histogenesis of lipomatous tumors of the uterus is controversial and many theories are proposed: (1) adipose metaplasia of smooth muscle or connective tissue into fat cells, (5) lipoblastic differentiation from misplaced embryonic fat cells, (3) proliferation of perivascular fat cells accompanying the blood vessels into the uterus. ${ }^{1-4,8,10}$

Lipoleiomyoma is frequently intra-mural and located in the posterior wall of the uterine corpus, but occasionally, may arise in the cervix. The diameter varies from millimeters to about 30 centimeters, with an average of between 5 and 10 centimeters. Macroscopically, the tumor resembles a leiomyoma, except for the yellow coloration characteristic of the adipose tissue that is scattered throughout the tumor. 2,8

Histopathologically, there are three types of uterine tumors with a lipomatous component 2,10 : the pure lipoma consisting predominantly of fat cells (adipocytes) with very few scattered smooth muscle cells, the lipoleiomyoma with a variable quantity and distribution of adipocytes and smooth muscle cells, and, finally, the form with prominent vascular structures admixed with adipocytes and smooth muscle cells (angiomyolipoma).

The clinical presentation and course of

\section{References}

1. Devooghdt M, Favoreel N, Gryspeerdt S, van Holsbeeck B Uterine lipoleiomyoma. JBR-BTR. 2012; 95: 31

2. McDonald AG, Dal Cin P, Ganguly A, Campbell S, Imai Y, Rosenberg AE, Oliva E. Liposarcoma arising in uterine lipoleiomyoma: a report of 3 cases and review of the literature. Am J Surg Pathol. 2011; 35: 221-7.

3. Vamseedhar A, Shivalingappa DB, Suresh DR, Geetha RL. Primary pure uterine lipoma: a rare case report with review of literature Indian J Cancer. 2011; 48: 385-7.

4. Wang X, Kumar D, Seidman DJ. Uterine lipoleiomyomas: a clinicopathologic study of 50 cases. Int J Gynecol Pathol. 2006; 25 : 239-42. lipoleiomyomas is similar to that of ordinary leiomyomas, which they are frequently associated with. As in the case reported here, they are usually asymptomatic. $2,4,8$ In the past, correct diagnosis of uterine lipoma was only possible through surgery or autopsy. However, with advances in imaging techniques, diagnosis can be carried out without surgery. $2,8,10$

Nevertheless, despite advances in transabdominal and transvaginal ultrasound imaging, the diagnosis may be difficult. Ovarian tumors containing fat and/or calcification, such as dermoids, may appear similar on ultrasound. Pelvic lipomas or liposarcomas may also be considerations. Even if a mass is found to derive from the uterus, it may be difficult to differentiate a fatty tumor from a degenerating fibroid. 8

Ultrasound scanning usually shows a hyperechoic mass partially encased by a hypoechoic rind.2,7,8 The rind is thought to represent a layer of miometrium surrounding the fatty component. Computed tomography scanning may show more specific findings, revealing a well-circumscribed, predominantly fatty mass with areas of nonfat soft tissue density deriving from the uterus. 5 Finally, magnetic resonance shows the lipomatous nature of the lesion with a high signal intensity on T1weighted images and chemical shift artifacts in the lesion. 8,10

Because of their benign nature, asymptomatic lipoleiomyomas require no treatment.1,2 In our case, the diagnosis of lipoleiomyoma was occasional and the vaginal hysterectomy was performed because of the uterine prolapse. The fact that the presence of a miometrial tumor was not detected by ultrasound transvaginal scanning will be discussed with the service where this examination was carried out, in order to improve the service for similar cases.
5. Avritscher R, Revathy B, Jae Ro I, Whitman G. Lipoleiomyoma of the Uterus. AJR. 2001; 177: 856.

6. Prieto A, Crespo C, Pardo A, Docal I, Calzada J, Alonso P Uterine lipoleiomyomas: US and CT findings. Abdom Imaging. 2000; 25: 655-7.

7. Mylona S, Giannoulakos N, Roppa-Lepida N, Koutsodimitropoulou A, Batakis N. Uterine lipoleiomyoma: transvaginal ultrasound and computed tomography findings of an unusual entity. Eur Clinics Obstet Gynaecol. 2008; 3: 315-7. 
8. Aung $\mathrm{T}$, Goto $\mathrm{M}$, Nomoto $\mathrm{M}$, Kitajima S, Douchi $\mathrm{T}$, Yoshinaga M, Yonzawa. Uterine lipoleiomyoma: a histopathological review of 17 cases. Pathol Int. 2004; 54: $751-8$.

Recebido em 28 de agosto de 2013

Versão final apresentada em 16 de setembro de 2013

Aprovado em 25 de setembro de 2013
9. Tsushima Y, Kita T, Yamamoto K. Uterine lipoleiomyoma: MRI, CT and ultrasonographic findins. British J Radiol. 1997; 70: 1068-70. 